Vera A. Vratuša ${ }^{1}$

UDC 316.323 .73

Guest Editor

University of Belgrade

329.15(060.13)

Faculty of Philosophy

Review paper

Department of Sociology

Submitted 05/07/2018

Belgrade (Serbia)

Accepted 09/07/2018

doi: 10.5937/socpreg52-18162

\title{
MANIFESTO OF THE COMMUNIST PARTY 170 YEARS AFTER THE FIRST EDITION: INTRODUCTION TO THE THEMATIC ISSUE OF SOCIOLOŠKI PREGLED / SOCIOLOGICAL REVIEW
}

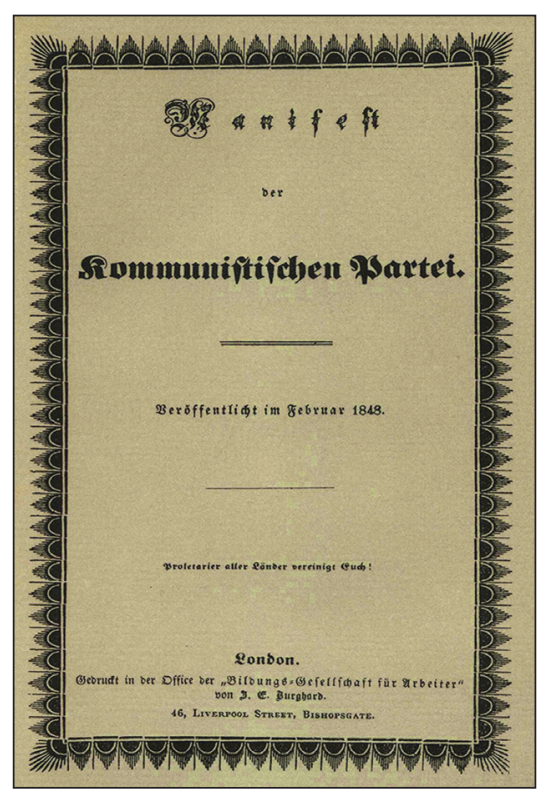

Photo 1: The cover of the first edition of the Manifesto of the Communist Party, 1848

Фотографија 1: Насловна корица првог издања Манифестй Комунистиччке йapūuje, 1848.
Abstract: One century and seventy years that passed since the first publishing of the Manifesto of the Communist Party (Marx, Engels, 1848), present a good reason to invite the interested authors to reflect on the actuality of main theses of Marx and Engels who summarized them already in this programmatic work while they were still in their twenties, elaborating these theses further in later works, closely related to ups and down of the proletarian class struggle. In the following paragraphs we will review the main theses that are still relevant for understanding the contemporary historical processes and for orienting the action of anti systemic social movements.

Keywords: Manifesto of the Communist Party, bourgeoisie, proletariat, small bourgeoisie, social revolution

One century and seventy years that passed since the first publishing of the Manifesto of the Communist Party (MCP; Marx, Engels, $1848 / 1982)$, present a good reason to invite the interested authors to reflect on the actuality of main theses of Marx and Engels who summarized them already in this programmatic work while they were still in their twenties, elaborating these theses further in later works, closely related to ups and down of the proletarian class struggle. In the following paragraphs we will review the main theses that are still relevant for understanding the

1 vera.veritas@gmail.com 
contemporary historical processes and for orienting the action of anti systemic social movements.

Karl Marx and Friedrich Engels wrote MCP on the eve of the uprising of working class which was formulating for the first time its own requests exceeding mare helping the change of a given fraction of bourgeoisie in power by some other fraction in industrial centers of France and Habsburg Empire. MCP has since become the most circulated, the most translated and the most influential strategic program document of any party and social movement in the world. To the present time there remains perceptible positive correlation between the publishing of different editions of the MCP and the tendency of the rise in anti-capitalist activity of proletariat in alliance with a part of old and new small bourgeoisie in the struggle against landowning, banking, industrial, world transnational financial big bourgeoisie and local comprador bourgeoisie based in the half-periphery and periphery of the world system of capitalistic economy (Wallerstein, 1980).

MCP presents in theoretical and methodological sense the implementation of the basic historical-materialistic and dialectic hypothesis that the economic reproduction of social life and from it necessarily arising contradictory social structure of productive forces and production relations of each historical epoch, make the material base for political and intellectual history of that epoch. Marx and Engels thought that as they were writing the MCP, relations of the capitalist private property and accumulation of capital were coming into the head- on contradiction with the colossal development of productive forces, causing ever stronger hyper accumulation of capital crises (Marx, Engels, 1982, p. 14). 170 years later we are witnessing the homologous cyclical crises manifested in simultaneous over production and unemployment.

Marx and Engels praised the progressive historical role of the bourgeoisie (Marx, Engels, 1982, pp. 11-13), of the owners of the means of production, in spite of its exploiting the hired workers as modern slaves, in as much as it eliminates remnants of the feudal property and absolutist social relations, systemically being unable to exist without permanent revolutionizing the means of production and accompanying social production relations, without exploitation of the markets of entire globe, replacing the old self-sufficiency of nations with their interdependence. Accentuating the low cost of products of industrialized nations as the main ammunition that tore down protective walls in countries like China (Marx, Engels, 1982, pp. 12) and failing to mention military aggression, Marx and Engels demonstrated that they were not immune to present the colonization from the point of view of the European colonizers.

Bourgeoisie ceases to be the historically progressive class and becomes ever more parasitic reactionary class impoverishing its hired slaves, thus proving its inability to reproduce systemic conditions of self-reproduction and therefore inhibits further development of production forces. It engages in the ever more violent search for extra profit on the basis of conquering ever cheaper sources of work-force, raw materials and markets throughout the planet. This process theoreticians in the last quarter of the $20^{\text {th }}$ century fashionably and class neutrally named globalization (Held et al, 1999). Contemporary bourgeoisie in its incessant pursuit of extra profit destroys the suppositions for the very biological survival on the planet through imperialistic wars, pollution and exhaustion of non-renewable natural resources.

Quite in accordance with their conviction that there came to the sharp structural polarization of all industrially most developed societies on bourgeoisie and proletariat, 
Marx and Engels little mention small peasants and agricultural workers. During the Paris commune, however, they realized that one of the reasons for its demise was the inability to contact and unite forces with the communes in the countryside with peasant majority. It were the revolutionaries of the twentieth century whose leaders realized that peasantry, great majority of population in their countries, had to become the major force of the revolution, and not the scarce proletariat.

MCP authors criticize small bourgeoisie, small industrialist, small merchant, artisans, small farm peasant, as reactionary in social and political sense even though they fight against big bourgeoisie, since they want to maintain the small property earned through its own work, which is continuously being eliminated by the development of big capitalist property (Marx, Engels, 1982, p. 23) through concentration and centralization of capital. In imperialist countries they also participate in the consumption of one part of the imperialistic extra profits that big bourgeoisie appropriates in colonies and semicolonies. Socialist oriented affiliates of the small bourgeoisie are according to Marx and Engels inclined to social charlatanism and reformist ragpickering which do not jeopardize profit of capitalists, as they are counting on the support of "educated classes", meaning propertied classes, for carrying out their moralizing philanthropic reforms without revolution (Marx, Engels, 1982, pp 34-38).

Marx and Engels structurally themselves belonged to the often opportunistic small bourgeoisie, but noticed from their own experience that in revolutionary situations one part of intellectual small bourgeoisie becomes revolutionary and comes over from the social standpoint of small proprietors to the social standpoint of the proletariat (Marx, Engels, 1982, p. 19) realizing the necessity of the elimination of private property relations as such for the emancipation of everybody. Sarcastic critics could claim that this coming over of Marx was in great part forced upon him, since he could not as persecuted revolutionary thinker support himself and the family from his writings. Engels is the example for the capitalist who came over to the standpoint of the proletariat by investing profits from the inherited textile factory into the financing of revolutionary activity of Marx and himself. Affiliates of the small bourgeoisie so far, however, seldom, if ever, exercised what revolutionary theorist and activist Amilcar Cabral (Cabral, 1967) from Guinea Bissau demanded from small bourgeois co-revolutionaries, to exercise the class suicide in order to be reborn in the role of self-organized proletarians. Instead of this collective suicide, most leaders of anti-colonial revolutionary movements, became themselves the main source of perpetuation of the class division of labor on the rulers and ruled, which is the legal expression for private property.

Oponents of Marx and Engels often criticize them for allegedly inspiring organization of the one party state rule of communists after social revolutions which they themselves did not experience, apart from the short lived Paris commune. Marx and Engels supported the leading role of the communist party members belonging to the wider and pluralistically organized workers movement, just in so far as they were able to better understand the conditions, the course and general results of the proletarian movement and to defend the common interests of the world proletariat in the everyday fights against the bourgeoisie, which are national in their form, but international in their substance (Marx, Engels, 1982, 20). Common to them all is the fight for the elimination of private capitalist property relationships, embedded in the class division of labor. Engels explicitly repeats 
in his 1872 Introduction to the MCP after the experiences gained in 1871 during the twomonths existence of the Paris Commune, that working class cannot simply appropriate a ready made state machine and put it in motion for its own goals, but it has to establish self-managing form of political self-organization of the society that is suitable for the simultaneous economic emancipation of the working class (50).

Lifelong engagement of Marx and Engels concerns the proletarian revolution. During their lifetime, they so in Paris commune the finally discovered political form for economic liberation of the proletariat. In spite of recurrent renewal of this democratic organization form in the heroic phases of social revolutions which erupted during and after their lifetime, so far have not been realized on the planetary level. This unrealized expectation of proletarian revolutions in the most industrialized European countries and US urges us to look for the explanation, together with the Engels and later authors coming from extra - European milieus (see Amin, 2017), in the corruption of the working classes in the most industrialized nations by their participation in the colonial and neocolonial extra profits. It seems that the gap between the particular empirical consciousness of various proletariat fractions, summarized in the request for increasing wages, on the one side, and their potentially universal class consciousness that they cannot free themselves from the class exploiting and oppressing them without simultaneously liberating the entire society from exploitation, oppression and class struggle, on the other, widened rather than narrowed down. Whenever working class allies itself with the national bourgeoisie in the fight against the working classes of neighboring countries, or of present and former colonies and semicolonies, it helps perpetuate the capitalist mode of social reproduction. The exhortation of Marx and Engels to proletarians of all countries to unite, ever since did not materialize, calling into question their claim that proletarians have nothing to lose in social revolution and that they do not have a homeland, especially those living in old and present imperialist powers.

Prerequisite for the eventual future successful social revolution consists also in drawing lessons from different interpretations and experiences of autocratic implementation of the thesis of the MCP authors about the avant-garde ideational role of the communist party among other democratic oppositional parties as the form of self-organization of workers throughout the class fight, like chartists in England and socialists in France. The communist parties which are expression of real relations of existing class fight and part of the real social movement of the proletariat against bourgeoisie, should have had only ideological and theoretical leadership in so far as their members comparatively better understand the conditions, process and general results of the proletarian movement in comparison to other workers' parties, defending common interest in different national settings (Marx, Engels, 1982, pp. 22-23). In real history of the twenties century, communist parties transformed themselves into single ruling parties after coming to power. This leaves to future revolutionaries to accomplish such seizing of the political power which will not perpetuate class division of labor between the rulers and ruled in the form of bureaucratized party and state apparatuses.

One of the main socially structured obstacles on the road of accomplishing the final combat cry of the MCP "Proletarians of All Countries, Unite!"( Marx, Engels, 1982, p. 46), should be searched for in the empirically unconfirmed assumption of Marx and Engels that proletariat as a whole has neither motherland nor property to lose in the 
social revolution except for the chains. This assumption neglects the insight of Marx and Engels themselves in other writings that the so-called working aristocracy of imperialist countries may arise which participates in crumbs from the table of exploited colonies and semi-colonies.

Another obstacles on the road of accomplishing revolutionary unity of all workers of the world, is implicated in the belief of Marx and Engels that the workers' movement should previously participate on the side of the national bourgeoisie in the struggle for conquering independence of national states, as the prerequisite of a sincere international cooperation and unification of proletariat around accomplishment of short-term and long-term common goals. The relationship between nationalism and internationalism was one of the points of dispute between Rosa Luxemburg and Lenin, the letter supporting the stance of Marx and Engels.

Marx and Engels did not prescribe recipes for the future organization of the society in local and global circumstances after the successful social revolution, assured that must be different in different social circumstances of given countries, In the review of the impact of the MCP on real social world, it would be interesting to investigate what is the current state of realization of the $\mathbf{1 0}$ points action program proposed by Marx and Engels in the field of property and labor legislation, economic, credit and fiscal policy of state administration, education. The most important of them concerning the abolishment of the capitalist private property was carried out only in revolutionary phases of social revolution, letting it return when their leaderships were forced to increase the productivity especially in agriculture, due to threatening famine especially of the urbanized population.

It takes seasoned revolutionaries to know to draw the lessons for future fights from past defeats of proletariat in its struggle against bourgeoisie. Seasoned revolutionaries are namely aware that taking over the control over extended reproduction process and establishing a classless society of freely associated producers (and consumers), takes a long fight of many generations to come. They are able to see further than apparent apathy of the damned of the earth (Fanon, 1961) under the rule of the iron fist of financial oligarchy militarily organized into NATO. Small bourgeois skeptics point out to the numerous defeats of both theory and practice of social revolutions. Due to the insurmountable contradictions of the capitalist mode of production probably their generation too will witness, or even join, rebellions of the damned of the earth, of great majority against the ruling minority. All the defeats of the exploited and oppressed in the class struggle against bourgeoisie should be regarded as instructive experience until "sufficient" economic progress and spiritual development of working masses are reached, providing prerequisites for a fundamental transformation of society in social revolution instead of the mere substitution in the given moment of the dominant bourgeoisie fraction in state power. Having in mind all the destructive weapons at the disposal of the world ruling class, the question poses itself whether the material, spiritual and organizational conditions for a successful social revolution and transition into a classless society will mature soon enough, before violent and exploiting productivist economic logic of accumulating extra profit, destroys the planet in a nuclear war or an environmental catastrophe?

From the perspective of the affiliates of the intellectual small bourgeoisie, there might seem to be little probability of "boogeyman of communism" to start again to 
circle through the Europe and the world. The first and second generation who either experienced or were born soon after the carnage of the World War II, which only continued and left unsolved contradictions which gave birth also to the First World War, are more inclined to perceive the repeated rise of the boogeyman of fascism and of re-colonization of the planet by the world ruling class, financial oligarchy, with mediating help of the local comprador bourgeoisies at semi-periphery and periphery of the world system of capitalist economy. This perception is little modified by the reading of the printed or electronically accessible contemporary socialist and communist literature. As in the time of Marx and Engels, it can be categorized first of all as small bourgeois proclamation of the vision of desirable society (Marx, Engels, 1982, pp. 32-43), without the clear vision of the revolutionary subject which would realize the vision, since the hope in the revolutionary mission of the working people faded away. This passive observation research tactics, gives additional support to the status quo, demoralizing and disarming anti-capitalistic oriented social movements with revolutionary potential where they emerge. All affiliates of the intellectual small bourgeoisie planning to go over to the standpoint of the proletariat, should on the contrary attempt to participate in the rebellion of the damned of the earth (Fanon, 1961) against the genocidal and ecocidal dominant world capitalist system of social relationships. The slogan, proletarians of the world unite is actual even more today than 170 years ago. Various antisystemic social movements do exist, but are still looking for an adequate form of uniting, political coordination and organization of their activities, on the planetary scale.

Critics of the Manifesto reproach its authors their alleged determinism and eschatologic character like the claim which summerizes the first chapter stating that bourgeoisie is producing its own gravedigger, so that its demise and the victory of the proletariat are eqqually unavoidable (Marx, Engels, 1982, p. 21). We should not lose from our mind that after stating the main thesis that entire written history of all societies so far was the history of class fight, Marx and Engels also state that this fight, omnipresent and continuous, hidden or open, ends as a rule in revolutionary reorganisation of entire society, but they also mention the alternative possibility, the common ruin of classes which fought against each other (Marx, Engels, 1982, p. 7).

Marx and Engels underlined beside the internal contradiction of the capitalism as systemic roots of social revolution, as well the need for the development of revolutionary consciousness of the exploited and oppressed on the mass scale. Ideas of abolishment of exploitative and oppressive social relations, can become material force only when they grasp the hearts and minds of masses. This consciousness development is needed as well in order to make possible that exploited and oppressed overtake control of entire process of social reproduction, starting with the raising of the proletariat into the ruling class, winning of democracy (30), with the aim to construct social relationships enabling that free development of each individual becomes condition for free development of all (Marx, Engels, 1982, p. 31).

As much as theoreticians of the end of history (Fukuyama, 1992) almost all over the globe would like to avoid the next wave of social revolution, hoping that allegedly free enterprise and representative democracy definitively triumphed in the leading nations, social revolution is potentially reemerging out of the systemic contradictions, irrationality and destructiveness of accumulation of capital for the sake of accumulation of more 
capital in global proportions. Without the emergence of social revolution, the common ruin of both contending classes, world proletariat and the world bourgeoisie, becomes the possibility. As long as exists the main internal contradiction of the capitalist mode of social life reproduction, antagonistic clash between the social character of the production process and the private character of exploitation i.e. appropriation of the unpaid surplus labor of double-free wage workers, so long will there exist as well the counter - systemic revolutionary movements of exploited and oppressed against exploitation and oppression. The deterministically formulated phrase that the victory of the proletariat is unavoidable, can be understood also as a tool of self encouragement on the long road to realization of social relationships in which the free development of each individual will be the condition of the free development of human potentials of everybody. Marxe's discovery of the systemic causes of cyclical crises of over accumulation of capital and hyper production, does not imply at all the automatic demise of capitalism, especially when we take into account all the means of bourgeoisie has amassed to counter and subdue anti-capitalists movements of the great majority of population against the tiny ruling minority. Even in the case of coming to power in major imperialistic powers of reform oriented enlightened parties of the bourgeoisie, it is doubtful that reforms would ensue in systemic structural change of dominant capitalist mode of production. They structurally reproduce inequality, poverty, indignity and illiteracy of vast masses of world population, in spite of already existing productive forces of human labor to eliminate death from hunger and inaccessibility of elementary medical help. On the long road to classless society therefore we may expect beside attempts at evolutionary structural reformation of capitalism, as well eruptions of new social revolutions as midwifes of classless socialized humanity and humanized nature.

Relatively scarce reply to the very widely disseminated call for papers at the occasion of 170 years since the first publication of the MCP, presents indirect confirmation that at the least among members of the sociological domestic and international associations social revolution and communism are far away from their theoretical and practical interests. Editorial board of the journal Sociološki pregled/Sociological Review as well as guest editor are however happy to present to public papers that will catch the attention of readership because some of the authors come from countries out of Serbia and are able thus to bring into their interpretation broader international living experience of class fight for the classless world society.

With sadness in heart I inform the readers that the heart of Samir Amin, Egiptian and French political economist of the worldwide reputation, the spiritus movens and dear comrade of all visionaries and fellow soldiers of the transition from destructive and decadent system of the capitalist economy to socialism and communism, stopped to tick. One of his last manuscripts and the first which is published posthumosly, so that it can be considered as testementary, "The Communiste Manifesto, 170 Years Later “ (doi: 10.5937/ socpreg52-16323), Samir Amin had sent the first as answer to the call for papers to the guest editor of the thematic issue of Sociološki pregled/ Sociological Review no. 2/2018 dedicated to the 170 anniversary since the first publishing of the Manifesto of the Communiste Party.

Eternal glory and thanks to Samir Amin. 
Вера А. Вратуша ${ }^{1}$

Гост уредник

Универзитет у Београду

Филозофски факултет

Одељење за социологију

Београд (Србија)

\title{
МАНИФЕСТ КОМУНИСТИЧКЕ ПАРТИЈЕ 170 ГОДИНА ПОСЛЕ ПРВОГ ИЗДАҢА: УВОД У ТЕМАТСКИ БРОЈ СОЦИОЛОШКОГ ПРЕГЛЕДА
}

\author{
(Превоg In Extenso)
}

Сажетак: Сто седамдесет година које су протекле од првог издања Манифести $а$ Комунистиччке йарйије (Marx, Engels, 1848), представљају добар разлог да се упути позив заинтересованим ауторима да промисле о актуалности основних теза Маркса и Енгелса који су их резимирали већ у овом програматском раду док су били у својим двадесетим годинама, развијајући их даље у каснијим радовима, у тесној вези са успонима и падовима пролетерске класне борбе. У наредним параграфима направићемо преглед основних теза које су и даље релевантне за разумевање савремених историјских процеса, као и за оријентисање деловања антисистемских друштвених покрета.

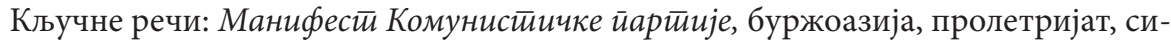
тна буржоазија, социјална револуција.

Сто седамдесет година протеклих од првог издања Манифестиа Комунистиччке йарйuje (МКП; Marx, Engels, 1848/1982), представљају добар разлог да се упути позив заинтересованим ауторима да промисле о актуалности основних теза Маркса и Енгелса који су их резимирали већ у овом програматском раду док су били у својим двадесетим годинама, развијајући их даље у каснијим радовима, у тесној вези са успонима и падовима пролетерске класне борбе. У наредним параграфима направићемо преглед основних теза које су и даље релевантне за разумевање савремених историјских процеса, као и за оријентисање деловања антисистемских друштвених покрета.

Маркс и Енгелс су написали МКП у предвечерје устанка радничке класе која је по први пут формулисала властите захтеве који су превазилазили пуко помагање промене дане фракције буржоазије на власти неком другом фракцијом у индустријским центрима Француске и Хабзбуршке империје. МКП је од тада постао највише растуран, највише превођен и најутицајнији програмски докуменат било које партије

\footnotetext{
1 vera.veritas@gmail.com
} 
и друштвеног покрета у свету. До садашњег времена је остала уочљива позитивна корелација између објављивања појединих издања МКП и тенденције успона антикапиталистичких делатности пролетаријата у савезу са деловима старе и нове ситне буржоазије у борби против земљопоседничке, банковне, индустријске и светске транснационалне крупне буржоазије и локалне компрадорске буржоазије, базиране на периферији и полупериферији светског система капиталистичке привреде.

МКП у теоријском и методолошком смислу представља примену темељне историјско-материјалистичке и дијалектичке поставке да економска репродук-ција друштвеног живота и из ње нужно настајућа противречна структура производних снага и производних односа сваке историјске епохе, чине материјалну основу за политичку и интелектуалну историју те епохе. Маркс и Енглес су сматрали док су писали МКП, да су односи капиталистичке приватне својине и акумулације капитала долазили у директну противречност са колосалним развојем производних снага, изазивајући све оштрије кризе хиперакумулације капитала (Marx, Engels, 1982, str. 14). После 170 година, ми смо сведоци хомологних цикличних криза манифестованих у истовременој прекомерној производњи и незапослености.

Маркс и Енгелс су хвалили прогресивну историјску улогу буржоазије (Marx, Engels, 1982, str. 11-13), власника средставазапроизводњуупркосњеном експлоатисању најамних радника као модерних робова, у мери у којој она елиминише остатке феудалне својине и остатке апсолутистичких односа и системски је неспособна да постоји без сталног револуционисања средстава за производњу и одговарајућих друштвених производних односа, без експлоатисања тржишта читавог света, замењујући стару самодовољност нација њиховом међузависношћу. Наглашавајући ниску цену производа индустријализованих нација као главну муницију која је срушила заштитне зидове у земљи као што је Кина (Marx, Engels, 1982, str. 12) и пропуштајући да помену војну агресију, Маркс и Енгелс су показали да нису били имуни на представљање колонизације са становишта европских колонизатора. Буржоазија је престала да буде историјски прогресивна класа и постала је све паразитарнија реакционарна класа осиромашујући своје најамне робове, тиме доказујући своју неспособност да репродукује системске услове саморепродукције, кочећи даљи развој проиводних снага. Она се ангажује у све насилнијим потрагама за екстрапрофитом на темељу освајања све јефтинијих извора радне снаге, сировина и тржишта на читавој планети. Савремена буржоазија у својем непрестаном трагању за екстрапрофитом уништава претпоставке за сам биолошки опстанак на планети кроз империјалистичке ратове, загађење и исцрпљивање необновљивих природних извора.

У потпуном складу са њиховим убеђењем да је дошло до оштре структуралне поларизације свих индустријски најразвијенијих друштава на буржоазију и пролетаријат, Маркс и Енглес су мало помињали ситне сељаке и пољопривредне раднике. Током трајања комуне у Паризу, међутим, схватили су да је један од узрока њеног пада била неспособност контактирања и уједињавања снага са комунама на селу са већином сељаштва. То су били револуционари двадесетог века чије су вође схватиле да сељаштво, велика већина становништва у њиховим земљама, мора да постане главна снага револуције, а не малобројни пролетаријат.

Аутори МКП критикују ситну буржоазију, мале индустријалце, трговце, занатлије, ситне сељаке, као реакционарне у друштвеном и политичком смислу упр- 
кос својој борби против крупне буржоазије, стога што настоје да одрежу ситно власништво стечено властитим радом које непрестано елиминише развој крупне капиталистичке приватне својине (Marx, Engels, 1982, str. 23) кроз концентрацију и централизацију капитала. У империјалистичким земљама они, такође, учествују у потрошњи једног дела екстрапрофита који крупна буржоазија присваја у колонијама и неоколонијама. Социјалистички оријентисани припадници ситне буржоазије су према Марксу и Енгелсу склони друштвеном шарлатанству и реформистичком крпарењу које не угрожава профит капиталиста, пошто рачунају на подршку „образованих класа”, дакле, класа крупних власника, за спровођење својих морализујућих филантропских идеја без револуције (Marx, Engels, 1982, str. 34-38).

Маркс и Енгелс су структурно и сами често припадали опортунистичкој ситној буржоазији, али су приметили из властитог искуства да у револуционарним ситуацијама један део интелектуалне ситне буржоазије постаје револуционаран и прелази са друштвеног становишта ситних власника на друштвено становиште пролетаријата (Marx, Engels, 1982, str. 19) схватајући неопходност елиминисања приватно власничких односа као таквих за еманципацију свију. Саркастични критичари би могли да тврде да је овај прелазак Маркса великим делом њему био наметнут, пошто није био у стању да као прогоњени револуционарни мислилац издржава себе и породицу од својег писања. Енгелс је пример наследника капиталисте који је прешао на становиште пролетаријата инвестирајући профит из текстилне фабрике у финансирање револуционарне активности Маркса и себе. Припадници ситне буржоазије до сада, међутим, ретко, уколико су уопште икада, извели оно што је револуционарни теоретичар и активиста Амилкар Кабрал (Cabral, 1967) из ГвинејаБисау захтевао од ситно буржоаских колега револуционара - да изврше класно самоубиство да би се поново родили у улози самоорганизованог пролетаријата. Уместо оваквог колективног самоубиства, већина вођа антиколонијалних револуционарних покрета, постали су сами главни извор овековечења класне поделе рада на управљаче и на оне којима се управља, која представља правни израз приватног власништва.

Противници Маркса и Енгелса често их критикују зато што су наводно инспирисали организовање једнопартијске државне власти комуниста након социјалних револуција које они сами нису доживели, осим краткотрајне Париске комуне. Маркс и Енгелс су подржавали водећу улогу чланова комунистичке партије која припада ширем плуралистички организованом радничком покрету, само утолико, уколико су они били у стању да боље разумеју услове, ток и опште резултате пролетерског покрета и да бране заједничке интересе светског пролетаријата у свакодневној борби против буржоазије, које су националне по форми, али интернационалне по својој садржини (Marx, Engels, 1982, str. 20). Свима им је заједничка борба за елиминисање односа приватне капиталистичке својине, утемељених у класној подели рада. Енгелс изричито понавља у свом Уводу за МКП из 1882. године након искуства стечених 1871. године током двомесечног постојања кумуне у Паризу, да радничка класа не може једноставо да присвоји готову машинерију државе и стави је у покрет за властите циљеве, него треба да успостави властите самоуправне облике политичке самоорганизације друштва који одговарају истовременој економској еманципацији радничке класе (Marx, Engels, 1982, str. 50). 
Доживотно ангажовање Маркса и Енглеса тиче се пролетерске револуције. Током њеног трајања, они су у Париској комуни видели коначно откривени политички облик за економско ослобођење пролетаријата. Упркос понављајућем обнавању овог демократског организационог облика у херојским фазама социјалних револуција које су избијала током и после живота Маркса и Енгелса, до сада нису остварени на планетарном нивоу. Ово неостварено очекивање пролетерске револуције у индустријски најразвијенијим земљама Еворпе и САД, наводе нас на то да потражимо објашњење, заједно са Енгелсом и каснијим ауторима пореклом из изван европских средина (в. Amin, 2017), у корумпирању радничке класе најиндустријализованијих нација кроз њихово учешће у колонијалним и неоколонијалним екстрапрофитима. Чини се да јаз између партикуларне емпиријске свести разних фракција пролетаријата, сумираних у захтеву за повећавањем најамнина, с једне стране, и њихове потенцијалне универзалне класне свести да не могу да ослободе себе од класног израбљивања, тлачења и класне борбе без да истовремено не ослободе целокупно друштво од израбљивања и тлачења, с друге, постаје све шири уместо да се смањује. Када год се радничка класа удружи са националном буржоазијом у борби против радничке класе суседних земаља, или садашњих и бивших колонија и полуколонија, она тиме помаже овековечење капиталистичког начина репродукције друштва. Позиви Маркса и Енгелса пролетаријату свих земаља да се уједине, од тада се нису материјализовали, доводећи у питање њихову тврдњу да пролетери немају шта да изгубе у социјалној револуцији и да они немају домовине, посебно у старим и садашњим империјалним силама.

Услов за евентуалну будућу социјалну револуцију састоји се и из извлачења поука за евентуалну будућу успешну социјалну револуцију из различитих тумачења и искустава аутократске примене теза аутора МКП о авангардној идејној улози комунистичке партије међу другим демократским опозиционим партијама као облика самоорганизације пролетаријата током класне борбе, као што су чартисти у Енглеској и социјалисти у Француској. Комунистичке партије које су израз стварних односа постојеће класне борбе и део стварног друштвеног покрета пролетаријата против буржоазије, требало је да имају само идеолошко и теоријско вођство утолико уколико су њихови чланови у поређењу са другим пролетерским партијама боље разумевали услове, процесе и опште резултате пролетерског покрета, бранећи заједничке интересе у различитим националним окружењима (Marx, Engels, 1982, str. 22-23). У стварној историји двадесетог века, комунистичке партије су се трансформисале у једине владајуће партије по доласку на власт. Ово оставља будућим револуционарима да остваре такво освајање политичке власти које неће овековечити класну поделу рада између управљача и оних којима се управља у облику бирократизованих партијских и државних апарата. Пролетаријат до сада није успео да ослободи себе и целокупно друштво од класне поделе рада на управљаче и оне којима се управља.

Једну од главних друштвено-структурираних препрека на путу остваривања закључног борбеног позива МКП „Пролетери свих земаља, уједините се!” (Marx, Engels, 1982, str. 46), требало би тражити у емпиријски непотврђеним претпоставкама Маркса и Енгелса да пролетери као целина немају ни домовину ни својину да изгубе у социјалној револуцији осим својих ланаца. Ова претпоставка занемарује увиде самих Маркса и Енгелса у другим текстовима о томе да може да настане та- 
козвана радничка аристократија империјалистичких земаља која учествује у мрвицама са стола експлоатације колонија и полуколонија.

Следећа препрека на путу остваривања јединства радника читавог света, имплицирана је у веровању Маркса и Енгелса да би раднички покрет требало претходно да учествује на страни националне буржоазије у борби за освајање независности националних држава, као претпоставке искрене међународне сарадње и уједињења пролетаријата око постизања краткороних и дугорочних заједничких циљева (Marx, Engels, 1982, str. 63-64). Однос између национализма и интернационализма био је једна од тачака спора између Розе Луксембург и Лењина у којем је Лењин подржавао становиште Маркса и Енгелса.

Маркс и Енгелс нису преписали рецепте за будућу организацију друштва у локалним и глобалним околносима након успешних социјалних револуција, убеђени да она мора да се разликује у различитим друштвеним условима одговарајућих земаља. У прегледу утицаја МКП на стварни друштвени свет, било би занимљиво да се испита какво је данас стање остваривања акционог програма у 10 тачака који су Маркс и Енгелс предложили у области законодавног регулисања својине и радних односа, економске, кредитне и пореске политике државне администрације, као и образовања. Најзначајнија тачка од њих која се тиче укидања капиталистике приватне својине, спроведена је само у револуционарним фазама друштвених револуција, дозвољавајући њен повратак када су њихове вође биле принуђене да повећају производност нарочито у пољопривреди, услед претеће глади нарочито урбаног становништва.

Потребни су прекаљени револуционари који знају да извлаче поуке за будућност из прошлих пораза пролетаријата у његовој борби против буржоазије. Прекаљени револуционари су, наиме, свесни да преузимање контроле над процесом проширене репродукције и успостављање бескласног друштва слободно удружених произвођача (и потрошача), захтева дуготрајну борбу великог броја будућих генерација. Они су у стању да виде даље од привидне апатије йрезрених на свейу (Fanon, 1961) под управом гвоздене песнице финансијске олигархије војно организоване у НАТО. Ситнобуржоаски скептици указују на бројне поразе како теорије тако и праксе социјалне револуције. Услед противречности капиталистичког начина производње који се не дају превазићи, могуће је да ће и њихова генерација бити сведок, или се чак придружити побунама презрених на свету, побуни велике већине против владајуће мањине. На све поразе израбљиваних и потлачених у класној борби против буржоазије треба гледати као на поучна искуства док се не постигне „довољан” економски напредак и духовни развој радних маса, обезбеђујући услове за темељни преображај друштва у социјалној револуцији, уместо пуке замене у датом моменту доминантне фракције буржоазије на државној власти. Имајући на уму сва разорна оружја на располагању светској владајућој класи, поставља се питање да ли ће материјални, духовни и организациони услови за успешну социјалну револуцију и прелаз у бескласно друштво сазрети довољно брзо, пре него што насилна и израбљивачка продуктивистичка економска логика акумулације екстрапрофита уништи планету у нуклеарном рату и катастрофи у природном окружењу?

Из перспективе припадника интелектуалне ситне буржоазије, може да изгледа да постоји мала вероватноћа да „баук комунизма” (Marx, Engels, 1982, str. 6) поново почне да кружи Европом и светом. Прва и друга генерација које су их доживеле 
или су рођене ускоро након Другог светског рата, који је једино наставио и оставио неразрешеним противречности које су породиле Први светски рат, склоније су да препознају успон баука фашизма и реколонизације планете од стране светске владајуће класе, финансијске олигархије, уз посредујућу помоћ локалне компрадорске буржоазије на периферији и полупериферији система светске капиталистичке привреде. Овакву перцепција мало мења читање савремене социјалистичке и комунистичке литературе. Као и у време Маркса и Енгелса, она се може разврстати пре свега као ситнобуржоаска прокламација визије пожељног друштва (Marx, Engels, 1982, str. 32-43) без јасне визије револуционарног субјекта који би остварио визију, с обзиром на то да је нада у револуционарну мисију радног народа избледела. Ова пасивна посматрачка истраживачка тактика пружа додатну подршку затеченом стању, деморалишући и разоружавајући антикапиталистички оријентисане друштвене покрете који имају револуционарни потенцијал тамо где се појаве. Сви припадници интелектуалне ситне буржоазије који планирају да пређу на становиште пролетаријата, требало би да, напротив, покушају да учествују у побуни йрезрених

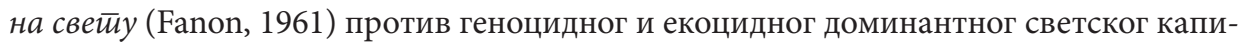
талистичког система друштвених односа. Слоган Пролетеери свих земаль, ујеgинитие ce! актуелан је још више данас него пре 170 година. Разни антисистемски друштвени покрети постоје, али још увек трагају за адекватним обликом уједињавања, политичке координације и организације својег деловања, на планетарном нивоу.

Критичари МКП приговарају ауторима текста због његовог наводног детерминистичког и есхатолошког карактера, и износе тврдњу која резимира прво поглавље саопштавајући да буржоазија производи властитог гробара, тако да су њена пропаст и победа пролетаријата подједнако неизбежне (Marx, Engels, 1982, str. 21). Не би требало да испустимо из вида да након саопштавања основне тезе да је целокупна писана историја свих друштава до сада била историја класних борби, свеприсутна и непрекидна, скривена и отворена, која завршава по правилу у револуционарној реорганизацији друштва, али они, такође, помињу алтернативну могућност, заједничку пропаст класа које су се бориле једна против друге (Marx, Engels, 1982, str. 7).

Маркс и Енгелс су нагласили, поред унутрашњих противречности капитализма као системских корена социјалне револуције, такође, потребу за развојем револуционарне свести масовних размера израбљиваних и потлачених. Идеје елиминације израбљивачких и тлачитељских друштвених односа, могу да постану материјална сила само када захвате срца и мисли маса. Овај развој свести је потребан, такође, да омогући да израбљивани и потлачени преузму контролу над целокупним процесом друштвене репродукције, полазећи од подизања пролетаријата у владајућу класу (30), са циљем изградње друштвених односа који омогућују да слободан развој сваке индивидуе постане услов за слободан развој свију (Marx, Engels, 1982, str. 31).

Ма колико би теоретичари краја историје (Fukuyama, 1992) готово широм света желели да избегну наредни талас друштвених револуција, надајући се да су наводно слободно предузетништво и представничка демократија дефинитивно тријумфовали у водећим нацијама, социјална револуција се потенцијално поново појављује из системских противречности, ирационалности и разорности акумулације капитала ради акумулације још више капитала у светским размерама. Без појаве социјалне револуције, заједничка пропаст обе класе у сукобу, светског пролетаријата и светске 
буржоазије, постаје реална могућност. Догод постоји основна унутрашња противречност капиталистичког начина друштвеног живота, антагонистички сукоб између друштвеног карактера производног процеса и приватног карактера израбљивања, тј. присвајања неплаћеног вишка рада двоструко слободних најамних радника, толико дуго ће, такође, постојати противсистемски револуционарни покрети израбљиваних и потлачених против израбљивања и тлачења. Детерминистички формулисана фраза да је победа пролетаријата неизбежна, може, такође, да се разуме као средство самоохрабривања на дугом путу ка остваривању друштвених односа у којима је слобода равоја сваке индивидуе услов слободног развоја људских потенцијала свију. Марксово откриће системских узрока цикличних криза над акумулацијом капитала и прекомерне производње, не имплицира ни у којем случају аутоматски распад капитализма, нарочито уколико узмемо у обзир сва средства која је буржоазија прикупила да се супротстави и потчини антикапиталистичке покрете велике већине становништва против незнатне владајуће мањине. Чак и у случају доласка на власт у главним империјалистичким земљама реформски оријентисаних просвећених партија, мало је вероватно да би реформе довеле до системских структуралних промена доминантног капиталистичког начина производње. Овај начин производње структурно репродукује неједнакост, сиромаштво, пониженост и неписменост широких маса светског становништва, упркос већ постојећим производним снагама људског рада за елиминисање смрти од глади и неприступачности основне здравствене заштите. На дугом путу до бескласног друштва, стога, можемо да очекујемо, поред покушаја еволутивних структуралних реформи капитализма, и избијање социјалних револуција као бабица бескласног подруштвљеног човечанства.

Релативно мали одзив на широко разаслати позив за радове за овај тематски број Социолошког прегледа посвећеног 170-годишњици првог објављивања МКП, представља посредну потврду да су барем међу припадницим домаћих и међународних социолошких удружења, друштвена револуција и комунизам далеко од теоријских и практичних интересовања. Уреднички одбор Социолошкої йреілеga, као и гост-уредник су веома срећни да представе публици радове који ће привући пажњу читалаца стога што део аутора долази из земаља изван Србије и јер су у прилици да унесу у своја тумачења међународна животна искуства класне борбе за бескласно друштво.

С тугом у срцу обавештавам читаоце да је престало да куца срце Самира Амина, египатског и француског политичког економисте светског угледа, покретачког духа и драгог друга свих визионара и сабораца транзиције из разорног и декадентног система светске капиталистичке привреде у комунизам и социјализам. Један од последњих својих рукописа и први који је објављен постхумно, тако да се може сматрати тестаментарним, “Комунистички манифест, 170 година после” (doi: 10.5937/socpreg52-16323), Самир Амин је послао први као одговор госту-уреднику на позив за прилоге у тематском броју Социолошкої йреїлеga 2/2018 који је посвећен

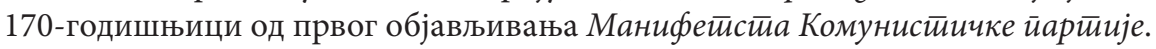

Вечна слава и хвала Самиру Амину 


\section{REFERENCES / ЛИTEPATУРA}

Amin, S. (2017). October Revolution 100 Years Later. Montreal: Daraja Press.

Cabral. A. (1969). Revolution in Guinea. New York and London: Monthly Review Press.

Fanon, F. (1961). The Wretched of the Earth. Paris: FM [In French]

Fukuyama, F. (1992). The End of History and the Last Man. New York: Free Press.

Held, D, Goldblatt, D, McGrew, A., Perraton, J. (1999). Global Transformations. Cambridge: Polity Press

Marx, K, Engels, F. (1982). The Manifesto of the Communist Party. Beograd: BIGZ [In Serbian]

Wallerstein, I. (1980). The Modern World-System. New York: Academic Press Inc 